\title{
Erratum to: K. Masumori, K. Maeda, Y. Koide, T. Hanai, H. Sato, H. Matsuoka, H. Katsuno, and T. Noro: Simple excision and closure of a distal limb of loop colostomy prolapse by stapler device
}

\author{
F. La Torre
}

Published online: 25 May 2012

(C) Springer-Verlag 2012

Erratum to: Tech Coloproctol (2012) 16:147

DOI 10.1007/s10151-011-0772-7

The title of this invited comment mistakenly contained the names of four people who were not authors of the original publication. The correct title is as given above.

The invited comment should also have included the original publication by Masumori et al. in its reference list.
The reference is as follows: Masumori K, Maeda K, Koide Y, Hanai T, Sato H, Matsuoka H, Katsuno H, Noro T (2012) Simple excision and closure of a distal limb of loop colostomy prolapse by stapler device. Tech Coloproctol 16:143-145.

The online version of the original article can be found under doi: 10.1007/s10151-011-0772-7.

F. La Torre $(\square)$

Department of Emergency, Colorectal and Pelvic Surgery

Unit - Policlinico Umberto 1, Sapienza University Hospital,

Rome, Italy

e-mail: filippo.latorre@uniromal.it 